\title{
Маркетингова комунікація в пострекламну епоху та українська практика
}

\section{Демченко М.В.}

\author{
Дніпровський національний університет імені Олеся Гончара
}

Розвиток цифрових технологій та Інтернету, особливо мобільного, вимагає зміни підходу до маркетингової комунікації. Традиційні канали й форми комунікації вже не такі ефективні, як раніше. Вони поступово втрачають авторитет і увагу аудиторії. Це зумовлено не тільки появою альтернативних джерел інформації, але й стрімким розвитком горизонтальних зв'язків і взаємопов'язаності завдяки соціальним мережам, що зруйнувало авторитет брендів на користь кола спілкування кожного споживача. Тепер він більше довіряє друзям, родичам або блогерам. Змінився також характер комунікації, вона більше не одностороння. Новий формат спілкування передбачає співробітництво й обмін, під час якого споживач очікує отримати дружню пораду, рекомендацію чи допомогу у вирішенні проблеми, яка його турбує особисто, або просто розважитися. Він прагне індивідуального ставлення до себе та можливості змінюватися за допомогою бренда. Все це вимагає перегляду підходів до маркетингової комунікації, що полягає не тільки у використанні цифрових технологій і даних, але й у зміні концепції взаємин бренда і споживача. У статті розглянуто новий підхід у сучасній маркетинговій комунікації та його реалізація в українській практиці.

Ключові слова: маркетинг; комунікація; споживач; digital-технології; соціальні мережі; нейромаркетинг; сторіноміка.

\section{1. Вступ}

Постановка проблеми. Розвиток Інтернету і digital -технологій зумовив не тільки появу нових форм i каналів комунікації, але й формування нового цифрового суспільства та цифрового споживача. Так, Філіп Котлер відзначає: «Опитування Google показує, що 90 \% нашої взаємодії із засобами масової комунікації тепер відбувається завдяки екранним пристроям: це смартфон, планшет, ноутбук і телевізійні екрани. «Екрани» стали настільки важливими в нашому житті, що ми використовуємо кілька екранів послідовно й одночасно тривалістю більше за чотири години у свій вільний час щодня. Інтернет $є$ основою цих взаємодій. Глобальний інтернет-трафік виріс у 30 разів із 2000 до 2014 рр., з'єднавши чотирьох із кожних десяти людей у світі» (Kotler, 2019).
Першим наслідком розвитку новітніх технологій стала втрата монопольної ролі традиційними засобами масової інформації, такими як телебачення, радіо, преса. Як стверджує Дерек Томпсон, «владою преси володіє кожен власник смартфона» (Thompson, 2018). Тепер у споживача $є$ величезна кількість джерел інформації, можливість вибору цих джерел і пошуку відповідей на будь-які питання, що цікавлять. Інтернет, особливо розвиток соціальних медіа, таких як Facebook, Twitter та Instagram, сформував нове коло авторитетів і експертів, якому довіряє сучасний споживач, - родичі, друзі, фоловери, блогери та ін. Наслідком цього стала втрата брендами монополії на комунікацію. Сучасний споживач здатний за допомогою Google отримати інформацію про будь-який продукт або послугу, зіставити ціни й характеристики та зробити свій вибір. Тепер бренду складно впливати на фор- 
мування бажаних уявлень про себе, адже споживач у змозі дізнатися про бренд масу подробиць і сформувати про нього думку, що може йти врозріз з його офіційною маркетинговою риторикою, вираженою в рекламі. «Коли споживачі не знають істинної цінності товарів, які вони хочуть купити, у своїх пошуках вони покладаються на корпоративну символіку. Але коли вони розуміють цінність продукту самого по собі, вони ігнорують рекламу й бренди» (Thompson, 2018).

Однак ігнорування реклами та брендів споживачами не єдина проблема, що позначилася на ефективності традиційних маркетингових звернень. Величезний потік інформації, з яким щодня стикається сучасний споживач, знизив рівень уваги до неї та її сприйняття. Ф. Котлер відзначає: «Середній житель великого міста щодня отримує близько 2000 рекламних інформаційних повідомлень, з яких лише деякі затримуються в пам'яті до кінця дня. Рекламі, колись найефективнішому механізму створення бренда і просування нових товарів, загрожує ї̈ власний розвиток: чим ії більше, тим менше уваги вона привертає» (Kotler, 2010, с. 24).

Крім зміни комунікаційного поля, змінився і сам споживач. В умовах нових технологій та Інтернету виросло покоління, чия модель поведінки кардинально відрізняється від типової поведінки старшого покоління. Покоління міленіалів, або "Ртуть», як називає його Андрій Длігач, «неможливо утримати ні як співробітників, ні як клієнтів (ртуть у руці теж неможливо утримати). У них немає уподобань, вони новини черпають із соцмереж, вони живуть одним днем» (Dlihach, 2018). Це покоління не можна охопити традиційними засобами масової комунікації, більше того, воно уникає рекламного контенту, підключаючись до платформ і приєднуючись до співтовариств, де реклама або не розміщена, або сильно обмежена. «Риса, що відрізняє цей новий тип клієнтів від представників інших ринків, яких ми бачили раніше, - їхня тенденція до мобільності. Вони часто переїжджають до нових місць, часто їздять на роботу й назад з одного району в інший і роблять усе в житті швидко. Все повинно бути негайним і швидким. Оскільки користування цифровим середовищем для них природне, вони вирішують питання про купівлю будь-де та будьколи, використовуючи широкий спектр пристроїв. Вони цінують індивідуальний підхід брендів до взаємодії з клієнтами. Вони довіряють своїй мережі друзів і родині більше, ніж корпораціям і брендам» (Kotler, 2019, с. 28)

Сьогодні стало очевидно, що в умовах нового цифрового суспільства традиційні методи маркетингу вже не працюють або, принаймні, втратили ефективність. Такий стан справ вимагає пошуку нових підходів. I це не просто використання нових цифрових каналів комунікації і нових технологій, а зміна стратегії, концепції взаємин бренда й споживача.

Аналіз останніх досліджень і публікацій. У багатьох сучасних роботах, присвячених маркетингу, про- відні експерти відзначають, що розвиток Інтернету та цифрових технологій кинув виклик традиційним підходам у маркетинговій комунікації. Нова реальність вимагає створення нових концепцій взаємин бренда й споживача, нових стратегій у комунікації, які передбачають не тільки використання цифрових форм i технологій, але й переосмислення ролі споживача, його поведінкової моделі і стимулів, що визначають його вибір. Нові виклики вимагають ревізії маркетингової комунікації. Сьогодні потрібні нові рецепти їі ефективності.

На фундаментальні світові тренди звертає увагу гуру маркетингу Філіп Котлер. У роботі «Маркетинг 4.0. Від традиційного до цифрового» він стверджує, що розвиток сучасних технологій зумовив незворотні зміни в бізнес-середовищі. Сьогодні воно виглядає як більш горизонтальне, інклюзивне та соціальне. Ф. Котлер зазначає: «Виклик для маркетологів, що залучають нову аудиторію $€$ подвійним. По-перше, маркетологам треба привернути увагу клієнтів. Бренд -менеджеру буде важко переконати клієнта подивитися 30-секундну рекламу, а продавцю - залучити клієнта за допомогою 30-секундної презентації. У майбутньому буде складніше донести меседж бренда. Увага клієнтів буде дефіцитом, тому вони звертатимуть увагу й підтримуватимуть лише бренди з «вауфактором». По-друге, маркетологам необхідно починати обговорення брендів у спільнотах клієнтів, хоча вони не зможуть точно гарантувати результат. Маркетологи мають бути впевнені, що коли клієнти запитуватимуть в інших осіб про бренд, існуватимуть захисники бренда, які будуть спонукати прийняти рішення на його користь» (Kotler, 2019, с. 38). Головна ідея Філіпа Котлера полягає в тому, що тепер завданням бренда $є$ не тільки й не стільки перетворення споживача на клієнта, а можливість зробити з нього свого пропагандиста. В умовах превалювання горизонтальних відносин і взаємопов'язаності завдяки насамперед соціальним мережам та перемикання фокусу довіри споживача з маркетингової комунікації на своє оточення, дуже важливо, щоб цей споживач добровільно рекомендував бренд іншим, був його активним адвокатом. Досягнення такої мети вимагає встановлення довірчих відносин між брендом і споживачем, що передбачає прозорість і відкритість. Тільки так можна завоювати увагу й довіру споживачів, сформувати з них лояльних пропагандистів, що зрештою призведе й до комерційного результату.

В іншій роботі, «Латеральний маркетинг», Ф. Котлер наполягає на необхідності зміни підходу до маркетингової комунікації. Він стверджує, що якщо раніше бренд, розмістивши рекламний ролик в ефірі одного з нечисленних телевізійних каналів, мав право очікувати зацікавленість у своєму продукті від мільйонів споживачів, то в сучасних умовах такий підхід не працює. Сьогоднішній споживач має можливість вибору джерела інформації серед безлічі телевізійних і радіоканалів, сайтів, соціальних мереж і блогів. 
Така різноманітність вимагає від бренда задіяння у власній комунікації більшого числа каналів і носіїв поширення реклами, що зумовлює значне збільшення бюджету. При цьому ефективність не збільшується, оскільки «споживачі стали вибагливими. Вони все частіше ігнорують комерційні комунікації. Можливо, єдиний шлях залучення їх уваги - новизна» (Kotler, 2010, с. 26). Рішенням проблеми Котлер бачить у використанні в комунікації прийомів і елементів запозичених з інших сфер і практик. Суть латерального маркетингу як концепції сучасного маркетингу полягає у виході за межі узвичаєних форм, підходів, традицій, створенні нових комбінацій для досягнення ефекту новизни.

Ця думка суголосна ідеї, висловленій Рене Моборном та В. Чан Кімом у «Стратегії блакитного океану» (Kim Chan, Moborn, 2019). Вони також відзначають, щоправда більшою мірою стосовно продуктів, ніж маркетингової комунікації, що в умовах зменшення ринкових сегментів і зниження ККД маркетингових зусиль конкуренція стає все більш запеклою, при цьому прибуток компаній продовжує падати. Компанії все частіше вдаються до стратегії цінових воєн, що тільки погіршує становище. Ці сформовані старі ринки із жорсткою конкуренцією Р. Моборн і В. Чан Кім назвали «червоним океаном». Компаніям важливо вирватися 3 нього та створити свій, "блакитний океан», де немає конкуренції. На це спрямована стратегія новації цінності. «Компанії, що застрягли в червоному океані, дотримувалися традиційного підходу, прагнучі здолати конкурентів і намагаючись зайняти зручну для захисту позицію в межах наявного в галузі порядку. А ось творці блакитних океанів, як не дивно, не брали конкуренцію за точку відліку. Натомість вони послуговувались іншою стратегічною логікою, яку звемо новацією цінності. Новація цінності - це наріжний камінь стратегії блакитного океану. Ми називаємо її так, адже ви не зосереджуєте всі свої зусилля на боротьбі з конкурентами, а робите конкуренцію непотрібною, створюючи такий стрибок у цінності для покупців і компаній, завдяки якому відкриваєте новий, не охоплений конкуренцією простір ринку» (Kim Chan, Moborn, 2019, с. 3233). Як і Котлер, автори «стратегії блакитного океану» вважають, що для досягнення успіху на ринку необхідно вийти за межі правил і практик у своїй товарній категорії, знайшовши нові й важливі для споживача новації цінності в знайомих продуктах.

Про важливість створення визначного продукту пише й Сет Годін. Він наполягає, що такий продукт сам по собі вже $\epsilon$ ефективною маркетинговою комунікацією. Тільки він здатний привернути увагу сучасного споживача. Таку стратегію С. Годін називає «Фіолетова корова» (Godin, 2014, с. 14). Монополія телевізійної реклами, яка була найефективнішим засобом продажу будь-якого товару, пішла в минуле. Сьогодні втрачає вплив на споживача не тільки телебачення, але й радіо, газети, журнали. Тепер, на дум- ку Годіна, нове правило ефективності в маркетингу звучить так: «Створюйте визначні продукти, і люди, яким потрібні такі продукти, знайдуть їх самі» (Godin, 2014 , с. 29). При такому підході ми, по суті, маємо повернутися в часи, що передували рекламі, коли єдиним джерелом інформації був людський поголос. На сьогодні такий формат комунікації завдяки цифровим технологіям отримав нову форму - соціальні мережі.

Однак Дерек Томпсон вважає, що одного створення визначного продукту недостатньо. Важливий також вибір спільноти, якій цей продукт пропонується. Саме завдяки правильно обраному каналу дистриб'ютування інформації можна забезпечити продукту популярність і успіх. Інакше навіть найвизначніший продукт залишиться невідомим. Важливим чинником поширення нових ідей, на думку Дерека Томпсона, є сучасні соціальні мережі. У книзі «Хітмейкери. Наука популярності в епоху розваг» він наводить приклад виходу на ринок популярного сьогодні додатку Instagram. «Перш ніж відбувся дебют Instagram, його творці запропонували ранню версію свого дітища відомим знавцям інформаційних технологій, що проживали в Сан-Франциско, як-от підприємець Кевін Роуз, журналіст М. Сиглер, популяризатор технічних досягнень Роберт Скоубл і один із засновників Twitter Джек Дорсі. Ці знаменитості світу IT розмістили кілька фото, зроблених за допомогою Instagram, у Twitter, де в них було в цілому кілька мільйонів фоловерів. Завдяки такому впровадженню в уже існуючі мережі Instagram зумів охопити тисячі користувачів ще до своєї офіційної появи на світ. Успіх Instagram багато в чому був обумовлений характером спільноти, якій цей продукт пропонувався» (Thompson, 2018). Отже, ключовими факторами ефективності сучасної маркетингової комунікації стає не тільки сам продукт, до якого можна застосувати епітет «визначний», а й правильно вибрані канал і джерела комунікації.

Крім правильно обраного каналу та джерела комунікації, не менш важливі її стиль і форма. Вони залежать від особливостей сучасного споживача, чиї звички, уподобання та модель поведінки істотно змінилися в епоху цифрових технологій. Про це розмірковує Роберт Маккі: «Міленіали - важлива частина аудиторії до сорока років - не тільки уникають реклами, а й сміються з неї, майже агресивно звинувачують їі в бридких хвастощах та пустих обіцянках. Нещодавні дослідження свідчать, що за останні п'ять років телевізійна аудиторія, що охоплює людей до сорока років, скоротилась на 30 \%, натомість популярність вільних від реклами сервісів на кшталт Netflix стрімко збільшилась» (Makki, 2019, с. 11).

Нове покоління споживачів, маючи можливості вибору товарів, способу й місця покупки, вважає за краще здійснювати свій вибір на основі індивідуальних потреб і переваг. Саме з цим пов'язано зростання на ринку тренду крафтових продуктів, відмова від 
диктату й нав'язування споживчих рамок з боку провідних світових брендів. Відповідно «Новий шлях розвитку - це шлях довіри, а не собівартості. Всі бренди в 2025 р. - приватні марки (персоналізовані)», стверджує Андрій Длігач (Dlihach, 2018).

Персоналізація, відповідність індивідуальним особливостям - головна вимога сучасного споживача, який більше не хоче йти на компроміс при виборі продукту або послуги. Більшість сучасних продуктів орієнтовані на якогось середнього споживача, який нічого не має спільного зі споживачем реальним. Про це пишуть Джозеф Б. Пайн II і Джеймс Х. Гілмор в «Економіці вражень»: «Масова персоналізація та індивідуальний маркетинг створюють основу для розвитку відносин» (Pine, Gilmore, 2021, с. 183). Створення сприятливих відносин між брендом і споживачем формує довіру між ними.

Запит на персоналізацію стосується і маркетингової комунікації. Релевантне рекламне звернення має більше шансів, що споживач зверне на нього увагу. Це особливо важливо з урахуванням того обсягу інформації, що надходить до сучасного споживача щодня. Джек Траут і Стів Ривкін наводять такі дані: «До вісімнадцяти років молодий британець підпадає під вплив 140000 телевізійних рекламних роликів. У Швеції середньостатистичний споживач отримує приблизно 3000 рекламних звернень на день» (Trout, 2007). Ф. Котлер ділиться цікавими дослідними даними: «Опитування Національного центру біотехнологічної інформації показує, що середній період концентрації уваги людини знизився від 12 секунд 2000 р. до 8 секунд 2013 р.» (Kotler, 2019). І ця тенденція стосується не тільки традиційних каналів комунікації, як-от телебачення. Роберт Маккі пише: «Від 2008 року маркетологи стежать за феноменом, який називають банерна сліпота: користувачі інтернету буквально оминають очима рекламу на вебсторінках. Цей феномен виявили, коли відстежували погляд за допомогою обладнання, що моніторить рух очей, коли люди переглядають вебсторінку" (Makki, 2019, с. 29). А дослідження, проведене рекламним агентством Infolinks, довело: «Після прохання згадати останню переглянуту рекламу лише 14 \% опитаних змогли назвати компанію, бренд чи продукт» (Makki, 2019, с. 30). Це свідчить про те, що бренди витрачають мільйони на рекламу, а її ніхто не запам'ятовує. Чим не привід переглянути підхід до маркетингової комунікації?

Одним із рішень стала персоналізація маркетингової комунікації. Завдяки розвитку цифрових технологій з'явилася можливість адресувати маркетингове звернення саме тому, кого потенційно воно може зацікавити, і в той момент, коли потреба в пропозиції найбільш висока. Однак цифрові дані дозволили не тільки транслювати інформацію, релевантну конкретному одержувачу, вони вивели на новий рівень дослідження споживача та його переваг. «Остання тенденція в рекламі й маркетингу - персоніфікація, тобто створення комерційних послань під конкретні пот- реби людини. Мобільні пристрої можуть знати про своїх власників більше, ніж найближчий друг. Тому вони будуть вміти пропонувати продукти й послуги, що задовольняють потреби саме цієї людини» (Lewis, 2015). За допомогою аналізу Big Data можна точно описати портрет конкретного споживача, модель його поведінки, ціннісні установки та звички. Інформація про сайти, які він відвідує, на кого підписаний і що лайкає формує набагато більш об'єктивну картину, ніж результати традиційних соціологічних опитувань, де дані значно спотворені через горезвісний «людський чинник». На цей аспект звертає увагу Саймон Кінгснорт: : «Аналітика сягнула такого рівня, що ми можемо досліджувати ринкову поведінку споживачів у режимі реального часу, залучаючи демографічні дані, інтереси зі статистикою включно» (Kingsnort, 2019). Подібні знання створюють можливості для маніпулювання споживачем, надаючи йому інформацію, яка викликає або позитивні або негативні емоції залежно від мети комунікації. Досліджуючи сучасні цифрові можливості, Девід Льюіс зазначає: «Володіючи можливістю отримувати, зберігати величезні масиви даних і маніпулювати ними, цифрові пристрої мають доступ до практично необмежених знань не тільки про самі продукти, але й про їх користувача. Математичні методи, такі як байєсові мережі або спільна фільтрація, дозволяють цифровим пристроям з високою ймовірністю прогнозувати, що захочуть купити окремі споживачі, і надати їм відповідні рекомендації » (Lewis, 2015).

Але не тільки цифрові технології дозволяють поновому поглянути на сучасного споживача, краще вивчити та зрозуміти його. Останні досягнення в області психології та біології сформували новий напрямок у маркетингу - нейромаркетинг. У дослідженні «Нейромаркетинг: Візуалізація емоцій» Арндт Трайндл пише: «Новітні дослідження мозку показали, що поведінкою людини керує не розум, а емоції. За результатами цих досліджень і даних класичного маркетингу народилася така наука, як нейромаркетинг. Знаючи біохімію емоційних реакцій покупців, продавці можуть ефективно впливати на всі п'ять органів почуттів людини, застосовуючи позитивні подразники у вигляді запахів, музики, кольору, викладення товару» (Traindl, 2007). Поява таких технологій, як кількісна електроенцефалографія (кЕЕГ) та функціональна магнітно-резонансна томографія (фМРТ), допомогла багато чого розповісти про поведінку споживачів. А головне про те, що їх вибір і поведінка далеко не раціональні.

У той же час дослідники-психологи Даніел Канеман і Амос Тверські дійшли висновку, що людині властиві два типи мислення - емпіричне та раціональне. Вони назвали їх Система 1 і Система 2. Ось як описує ці системи Насім Талеб: «Система 1, або емпіричний тип мислення, не потребує зусиль, відбувається автоматично, проходить швидко, дозволяє паралельні процеси, припускає помилки, ми користуємося ним 
несвідомо. Система 2, або раціоналістичний тип мислення, - це по-простому думання. Ми вмикаємо "думання» в навчальних аудиторіях, адже воно потребує зусиль, ґрунтовне, повільне, логічне, послідовне, поступове й усвідомлене. Помилки чекають там, де працює Система 1, але ми думаємо, що користуємося Системою 2. Як так може бути? А так, що наші реакції спонтанні й несвідомі, Система 1 працює без відома людини - і це їі найголовніша особливість! Людина за самою природою не може надто довго й надто інтенсивно використовувати Систему 2 - потрібен відпочинок. Крім того, ми просто забуваємо про неї» (Taleb, 2017, с. 92-93). Отже, Канеман із Тверскі, як і нейробіологи, дійшли висновку, що поведінка споживача аж ніяк не раціональна. У книзі «Думай повільно, вирішуй швидко» Даніел Канеман наводить результати різних споживчих досліджень, де доводить ірраціональну природу нашої поведінки (Kahneman, 2020). До подібних висновків доходить i Ден Аріелі в роботі «Передбачувана раціональність» (Arieli, 2018).

Ця ідея була розвинена Ричардом Талером, який започаткував новий напрямок в економічній науці поведінкова економіка. У роботі «Нова поведінкова економіка. Чому люди порушують правила традиційної економіки і як на цьому заробити» він наполягає на тому, що раціональні моделі традиційної економіки не мають нічого спільного з реальним життям. Дослідник пише: «Основний постулат економічної теорії свідчить, що людина робить вибір, виходячи з можливого оптимального результату. 3 усіх послуг і товарів, які може придбати сім'я, вона обере найкращі з тих, що може собі дозволити. Більш того Раціонали здійснюють вибір неупереджено. Іншими словами, ми вибираємо, спираючись на те, що економісти називають раціональними очікуваннями. Однак $\epsilon$ проблема: постулати, на які спирається економічна теорія, не бездоганні. Ви знаєте, і я знаю, що ми не живемо у світі Раціоналів. Ми живемо у світі Людей. Пора перестати вигадувати відмовки. Нам потрібен оновлений підхід до проведення економічних досліджень, який визнає існування й важливість Людей» (Thaler, 2016).

Ґрунтуючись на поведінкових аспектах, відкритих психологами, і на останніх дослідженнях людського мозку, маркетологи отримали можливість створювати комунікацію, яка впливатиме на підсвідомість споживача, обходячи/оминаючи області раціонального прийняття рішень і критичного аналізу, формуючи певні автоматичні поведінкові звички й моделі.

Резюмуючи описані вище результати досліджень і досягнень науки, доходимо висновку, що в епоху цифрових технологій, споживачів покоління міленіалів, традиційні підходи й методи маркетингової комунікації не працюють. Сьогодні, щоб привернути увагу споживача, завоювати популярність, компаніям необхідно звернути увагу на такі аспекти: створення визначного продукту, вибір аудиторії, канал та дже- рело комунікації, форма й стиль комунікації. Це допоможе створити довірчі відносини між споживачем і брендом. І при цьому необхідне використання цифрових технологій, яке дасть можливість персоналізувати пропозицію, врахувати індивідуальні особливості та вподобання кожного клієнта. Саме ці чинники сьогодні визначають успіх і зумовлюють новий підхід до маркетингової комунікації.

Мета статті - визначити нові підходи, технології, форми й канали маркетингової комунікації, які будуть ефективні в умовах формування цифрового суспільства й цифрового споживача. 3'ясувати, як ці нові підходи застосовані та зреалізовані в українській практиці, яким чином можлива інтеграція традиційних і цифрових методів маркетингової комунікації.

Методи дослідження. У дослідженні використано аналіз контенту сучасної маркетингової комунікації українських брендів, результати відкритих досліджень українського ринку й споживачів та аналіз останніх досліджень і публікацій у сфері маркетингу. Вивчається реалізація сучасних підходів і технологій у маркетинговій комунікації в українській практиці. Крім того, виявляються особливості українського ринку та споживачів, які зумовлюють вітчизняну інтерпретацію сучасного маркетингу, що полягає в інтеграції традиційних і сучасних підходів.

\section{2. Результати дослідження}

Визначення суспільства як цифрового виражається не тільки ступенем поширення Інтернету й кількістю гаджетів, яким володіє населення, але більшою мірою користуванням цифровими технологіями й онлайн-сервісами, загальною цифрової культурою. Так, Саймон Кінгснорт наводить дані Національної статистичної служби Великобританії за 2014 р., з яких випливає, що лідерами за обсягом онлайн-покупок у Європі $€$ Великобританія, Данія і Швеція. Відсоток повнолітніх споживачів (16-74), які зробили онлайнпокупки за останній рік, у цих країнах складає понад $60 \%$. При цьому відсоток організацій, що торгують онлайн (принаймні, 1 \% від товарообігу), найбільший у Чехії та Данії - понад 20\%. (Kingsnort, 2019).

щодо диджиталізаціі, то Україна, безумовно, відстає від Європи та США. Але пандемія COVID-19 і пов'язані 3 нею обмеження стимулювали зростання використання цифрових технологій. Результати досліджень «Deloitte» в Україні 2021 року демонструють такі дані: 39 \% українців стали рідше купувати товари в класичних магазинах, водночас $18 \%$ респондентів відповіли, що віддають перевагу покупкам онлайн. Також 32 \% опитаних українців протягом наступних двох років планують більше купувати в онлайнмагазинах, у той же час 20 \% мають намір зменшити покупки в традиційних магазинах.

Результати споживчих досліджень, проведених Kantar TNS у 2018 р., засвідчують лідируючу роль традиційних каналів комунікації. За ступенем уваги лідирує телебачення (62 \% опитаних), на другому місці 
зовнішня реклама (39 \%) і лише на третьому місці Інтернет (37 \%). Але, за показником «відчуття користі», Інтернет як канал комунікації посідає друге місце, відстаючи від телебачення всього на 2 \% (16 \% і 18 \% відповідно).

Отже, в Україні, як і раніше, ефективні традиційні канали комунікації, при цьому чітко простежується тренд на все більшу диджиталізацію суспільства. 3 кожним роком буде все важче залучати увагу споживачів до свого бренда та зберігати споживачів у зоні свого впливу, застосовуючи лише старі підходи. Вже сьогодні видно, що цінові війни та експлуатація нечисленних селебріті в телевізійній і зовнішній рекламі приносять все менше результату, при цьому рік від року значно збільшується маркетинговий бюджет. А значить, саме час міняти концепцію комунікації і формат взаємодії зі споживачем.

Аналіз останніх публікацій і результатів досліджень дозволив виділити ключові фактори ефективності сучасної маркетингової комунікації. Це визначний продукт; правильно обраний канал і джерело комунікації, релевантне установкам і поведінковій моделі сучасного споживача; зміст, форма та стиль комунікації, що викликають емоції і дозволяють встановити зі споживачем довірчі відносини. Використання сучасних технологій і цифрових даних не тільки дають уявлення про поведінку споживача і його реальні мотиви, а й дозволяють впливати на споживчі дії і вибір, персоналізувати маркетингову комунікацію. Як цей новий підхід до маркетингової комунікації реалізується в українській практиці?

Визначний продукт як маркетингова комунікація

Суголосно з рекомендацією Сета Годіна, погодимося, що сам продукт може привертати увагу споживача за умови, що він визначний. Однак більшість продуктів з точки зору споживчої цінності є звичайними. Далеко не кожній компанії вдається знайти свій «блакитний океан». А значить, вони повинні досягати результату в умовах жорсткої конкуренції. Але для того, щоб зробити продукт визначним в очах споживача, зовсім не обов'язково шукати новацію цінності. Цілком достатньо створити враження визначного продукту. Джек Траут зазначає: «Маркетингова війна ведеться на полі бою завширшки якихось 15 сантиметрів - у голові потенційного клієнта. Це одне з найголовніших понять для розуміння суті маркетингу. Ви не можете виграти завдяки кращому продукту. Ви можете виграти завдяки кращому сприйняттю» (Trout, 2020, с. 62).

Важливіше від самого продукту уявлення про нього, сформовані в голові споживача. А для того, щоб уявлення про продукт було як про визначний, необхідно вразити. Про маркетинг вражень як особливий і найважливіший сьогодні напрямок просування товарів і послуг пишуть Джозеф Б. Пайн II і Джеймс Х. Гілмор (Pine, Gilmore, 2021). Форма, подача, дизайн, процес, атмосфера - все стає елементами постановки вистави, покликаної вразити спожи- вача, привернути його увагу й виокремити продукт 3 ряду подібних. На українському ринку сьогодні удосталь прикладів реалізації подібного підходу, починаючи від використання зображень селебриті на етикетках та упаковках до справді оригінальних ходів. Наприклад, зовнішній вигляд негазованої води бренда VODA иa, що розлита в упаковку тетрапак, яку використовують для молочних продуктів, чорного кольору. Такий дизайн, форма і тип упаковки, по суті, $€$ маркетинговою комунікацією, що робить товар помітним. Ще одним прикладом може бути служба доставки «Globo». Ï̈̈ кур'єри з упізнаваними фірмовими жовтими рюкзаками, які стали об'єктом безлічі мемів, є ефективними рекламними носіями, звертають на себе увагу й запам'ятовуються.

Канали маркетингової комунікації цифрового споживача

Сьогодні найбільш потужним каналом комунікації у світі $€$ мобільний Інтернет, що пов'язано із зростанням продажу смартфонів. Налаштувавши свій гаджет під індивідуальні потреби й переваги, тепер кожен має в кишені власне джерело й канал комунікації. Перевіряти смартфон на предмет нових повідомлень уже ввійшло у звичку сучасної людини. Нір Еяль і Раян Гувер наводять такі дані: «Щоранку одразу після пробудження 79 \% власників смартфонів перевіряють свої пристрої щонайменше 15 хвилин. Неймовірно, але третина опитаних американців стверджує, що воліла б краще відмовитися від сексу, аніж втратити свій мобільник. Під час університетського дослідження в 2011 р. було з'ясовано: у середньому люди перевіряють свої телефони 34 рази на день. Однак інсайдери, які володіють детальнішою інформацією в цій галузі, вважають, що це число наближається до вражаючої позначки в 150 разів» (Eial, 2017, с. 9).

Активне користування смартфонами виявило ще одну особливість - бажання користувачів ділитися інформацією, перш за все персональною. «Дослідження свідчать, що більше 40 \% обговорюваних тем стосуються персонального досвіду чи особистих стосунків. Близько половини твітів сконцентровані навколо «Я», розповідають, що людина робить або що із нею сталося» (Berger, 2016, с. 36). Навіщо люди це роблять? Тому, що вони хочуть отримати винагороду - суспільне визнання у вигляді лайків, коментарів, перепостів тощо. Саме цей принцип дозволив вирости таким каналам комунікації, як соціальні мережі. Так, Ф. Котлер відзначає, що «найгустонаселеніша «країна» у світі - це «Сполучені Штати Фейсбуку» 3 населенням 1,65 млрд осіб» (Kotler, 2019, с. 13-14).

Соціальні мережі як канал маркетингової комунікації сьогодні дуже важливий. Але для того, щоб привернути увагу користувача до свого бренда, викликати в нього зворотну реакцію, бажання поставити лайк або поділитися вашим постом, стати вашим пропагандистом, необхідно створити контент, який дозволить споживачеві постати у вигідному світлі. Українсь- 
кі ж бренди частіше застосовують до Інтернету, і зокрема до соціальних мереж, традиційний підхід - підхід мегафона. Іншими словами, використовують їх як ще один односторонній канал комунікації, як телебачення чи радіо. Практично всі українські бренди мають сайти й акаунти у Facebook та Instagram. Так, завдяки аналітиці Google, Facebook, Instagram все більше рекламних кампаній розміщуються за таргетпринципом - тобто видимі тій аудиторії, яка потенційно зацікавлена в конкретній пропозиції. Але все одно така маркетингова комунікація залишається традиційною рекламою, ефективність якої, незважаючи на використання сучасних цифрових каналів комунікації та персоналізації, невисока.

Конвент-маркетинг як умова створення зв'язків зі споживачем

Сьогодні, для того щоб маркетингова комунікація була ефективна, щоб споживачі помітили ваш бренд, щоб між ними й брендом сформувалися довірчі взаємини, які викликатимуть бажання рекомендувати, необхідно відмовитися від традиційного маркетингу, який Браян Гелліген називає «вихідним маркетингом»: «Проблема цих традиційних маркетингових прийомів полягає в тому, що вони втратили свою ефективність як поширювачі інформації, оскільки люди почали краще їх блокувати» (Gelligen, 2020, с. 21). Новий підхід, який він називає «вхідним маркетингом», полягає в тому, щоб залучати споживача до спілкування, а не просто транслювати маркетингову інформацію. Залучення може відбутися, тільки якщо контент бренда цікавий і корисний. I при цьому, як вважає Майкл Стелзнер, безкоштовний. «Перестаньте нав'язувати споживачам свої бажання - йдіть за ними і спостерігайте за тим, що відбувається. Люди не хочуть, щоб їм що-небудь нав'язували. Їм потрібно всього лише отримати достатньо інформації, щоб зробити свій вибір, і ця інформація повинна бути безкоштовна» (Stelzner, 2012). Важлива й корисна інформація у вигляді подарунка викликає в одержувача відчуття зобов'язання, що спонукає до повернення такого психологічного боргу, наприклад, у вигляді передплати на контент бренда. Контент-маркетинг дозволяє сформувати імідж бренда як друга, з яким можна обговорити цікаву тему, і як експерта, чия думка й рекомендація важливі для прийняття рішення. Сучасний споживач шукає необхідну інформацію в Google, цікавиться думкою блогерів - експертів у різних сферах і лідерів думок різних спільнот і ділиться інформацією в соцмережах. Відповідно конвент-маркетинг повинен охоплювати всі три ці напрямки.

Однак проблема полягає в характері наповнення. Сайти й акаунти в соціальних мережах скоріше представляють собою різновид рекламного звернення (формалізованого й одностороннього) у більш-менш розширеному вигляді, у форматі мультимедіа. Вони позбавлені живої інформації, яка має зацікавити користувачів у підписці та спілкуванні. Якщо коротко, то вимогу до ефективного контенту можна сформулювати так: він повинен вражати. А вражати він може, тільки якщо розважає, є корисним і цікавим. Певною мірою відповідають цим вимогам сайти «Моршинська» і «Галичина», які у підході до контенту намагаються у свідомості споживача посісти місце експерта у своїх областях, намалювати образ натуральних, природних продуктів. Цікавим також виглядає акаунт у Facebook «Клініка сімейної медицини» (мережа з міста Дніпро), який створений в неформальному стилі, і надає багато корисної та цікавої інформації своїм передплатникам.

Блоги також стали одним із популярних каналів комунікації українських брендів. Але самі бренди блоги не ведуть, вважаючи за краще просувати себе за допомогою відомих і популярних українських блогерів. Однак ця співпраця більше схожа на звичний підхід до роботи із селебриті, де основним критерієм ефективності $€$ зовнішні показники, тобто популярність, виражена кількістю передплатників, і мало хто звертає увагу на теми та проблеми, які об'єднують певну спільноту навколо конкретного блогера. Зрештою часто відбувається ситуація, коли рекламовані блогером продукти не релевантні його аудиторії. Хоча потрібно визнати, що не кожен блогер готовий ризикнути своєю репутацією і напрацьованою спільнотою заради винагороди за рекламу не цікавого їй продукту. Візьмемо, наприклад, такого популярного українського блогера, як Олена Мандзюк, яка має 1,2 млн підписників. Звичайно, за своїм охопленням це ефективний канал комунікації. Але не можна забувати, що тема блогу і, відповідно, інтереси аудиторії обертаються навколо материнства, моди та здоров'я. Тож, реклама продуктів і контент, пов'язаний з ними, повинні відповідати змісту цього блогу. В іншому випадку результату не буде.

Сторіноміка як новий формат маркетингового повідомлення

3 наведених вище результатів досліджень бачимо, що в Україні, як і раніше, мають вагу традиційні маркетингові канали комунікації, передусім телебачення. Практично кожен національний телеканал представлений в інтернеті і соціальних мережах. Так, «ТС » - телевізійна служба новин каналу «1+1»- має сайт і сторінку у Facebook з майже 1 млн фоловерів. У такий спосіб, втрачаючи увагу традиційного глядача, телебачення заповнює її за рахунок розвитку у форматі «нових медіа». Таку тенденцію спостерігаємо в усьому світі. За перетворенням форми, відбувається й перетворення змісту. Щодо маркетингової комунікації, то зазначимо, що зараз з'явився такий напрямок, як сторіноміка. На зміну традиційній рекламі, яка лише декларує переваги й нав'язує думку споживачам, які завдяки Інтернету можуть отримати необхідну інформацію про продукт і бренд, приходять історії, що викликають не просто емоції, а почуття, здатні сформувати міцні й довготривалі емоційні зв'язки між споживачем і брендом. Роберт Маккі пише: «Цінності історії - це універсальні властивості людських переживань і досвіду, що в якийсь момент 
можуть бути то позитивними, то негативними» (Makki, 2018).

Історія не тільки покликана олюднити бренд, надати йому людських рис характеру і тим самим зробити його ближчим і зрозумілішим споживачеві. Історія має показати, як він за допомогою бренда може змінитися, реалізувати мрії та прагнення. Так, Маккі в роботі «Сторіноміка» описує приклад рекламної історії бренда «Dove» (Makki, 2019, с. 87). Тюремний художник малює портрети звичайних жінок, не бачачи їх, а ґрунтуючись лише на самоописі. Вони досить самокритичні й не вважають себе ідеальними. Потім цей художник малює портрети тих же жінок, але на підставі свідчень інших людей. При порівнянні портретів стає зрозуміло, що, портрети, написані на підставі вражень інших людей, більш правдиві та ідеальні. Побачивши різницю, учасниці проєкту були приємно здивовані, їх самооцінка підвищилася. Ролик набрав мільйони переглядів у YouTube. Але головний успіх полягав у іншому. Бренд «Dove», що дав можливість зробити жінкам-учасницям таке перевтілення, став для них уособленням впевненості в собі, джерелом поваги до себе й внутрішнього комфорту. Навряд чи тепер вони помічають в магазинах інші бренди і, тим більше, порівнюють споживчі характеристики мила.

Історії не тільки справляють враження, що дозволяє маркетинговим зверненням привернути увагу й запам'ятатися, вони дозволяють показати споживачеві, яку трансформацію він може зазнати за допомогою бренда. «Людині потрібно щось, що було б більш довготривалим, ніж спогади, щось, чого не може дати ні товар, ні послуга, ні враження ... кожен покупець трансформації, по суті, просить змінити його самого» (Pine, Gilmore, 2021, с. 323-336). У сьогоднішній українській практиці маркетингової комунікації такий контент відсутній. 3 натяжкою можна визнати сторіномікою рекламні ролики «Першої броварні», героєм яких є сам власник бренда. Він постає звичайною людиною, яка робить свою справу з любов'ю, веде спосіб життя, схожий на модель багатьох споживачів, а значить, викликає довіру й змушує співпереживати. Завдяки такому підходу бренд набуває цілком людських рис і стає ближчим до споживача. Але найчастіше в українській рекламній практиці реалізується підхід інтеграції продукту в повсякденні, типових для споживача, ситуаціях, а не створенні історії, що демонструє, як він може змінитися з допомогою бренда.

Нейромаркетинг і технології впливу на споживчу поведінку

Серйозних досліджень людської свідомості у сфері маркетингу за допомогою таких технологій, як кількісна електроенцефалографія (кЕЕГ) і функціональна магнітно-резонансна томографія (фМРТ), в Україні не проводять. Пов'язано це з високою ціною подібних досліджень. Але це не означає, що в маркетинговій практиці не використовують досягнення й від- криття нейромаркетингу та поведінкової економіки. Багато прийомів, запозичених із зарубіжної практики, реалізовано в нас насамперед у ритейлі. у багатьох національних мережевих магазинах використовують технології запахів, для того щоб стимулювати бажання споживача зробити покупку. Також давно в практику увійшли цінники з розміром ціни, що закінчується на 99. «...Вплив спотворення лівої цифри на готовність споживача платити відомо більше 75 років вперше в 1936 р. його відкрив Елі Гінзберг з Колумбійського університету. Однак його стали ретельно досліджувати лише недавно. Будь-який товар за ціною 9,99 буде сприйнятий більшістю покупців як дешевший, ніж той, що коштує 10, і дослідження показують, що від $30 \%$ до 65 \% цін закінчуються на дев'ятку. І це не тільки ціни. Спотворення лівої цифри виникає при будь-якої транзакції, у якій беруть участь цифри» (Lewis, 2015). Не менш поширений прийом обмеження товарної пропозиції, як-то «не більше чотирьох в одні руки», який підштовхує споживача брати саме чотири одиниці, а не одну.

Окремо виділимо напрямок, пов'язаний із візуальним сприйняттям продукту та комунікації. «Зір відповідає за 90 відсотків інформації. Око - це не камера, тому мозок не бачить цілісного зображення, сприйняття ґрунтується не на повних картинках. Мозок розкладає об'єкти на окремі компоненти, які потім поетапно збирає в цілісний образ, загальну структуру» (Barden, 2014, с. 103). Можливо тому так званий «європейський дизайн», що характеризується лаконічністю і чітко виділеним корпарайт-блоком сьогодні в тренді на українському ринку. Практично всі продукти українських брендів, які $€$ лідерами у своїх категоріях, мають помітний, впізнаваний дизайн і форму упаковки, що виділяються серед строкатості торгової полки. Серед них Villa Krim, Галичина, Моршинська, Shabo. Також поширений маркетинговий прийом - викладка на полиці у вигляді блоку, який представляє собою кольорову пляму, добре помітну навіть здалеку. Як приклад можемо навести слабоалкогольні продукти Shake.

У самих маркетингових зверненнях також часто зреалізовані технології, що змушують споживача запам'ятовувати потрібну замовнику інформацію мимоволі або не фіксувати у своїй свідомості приховані додаткові витрати. Отже, у цьому аспекті українські бренди розвиваються в руслі світових трендів, хоча й відстають у плані технологій.

\section{3. Обговорення}

Аналіз підходів у маркетинговій комунікації, що домінують на українському ринку, дозволяє дійти висновку, що в цьому плані Україна традиційна. Великий вплив на споживача мають класичні канали комунікації - телебачення й зовнішня реклама. Про це свідчать опитування споживачів. Щороку вартість ефективності зростає, бо, щоб бути помітним, фахівці з медіапланування рекомендують мати медіаголос 
вище середнього в своїй категорії. Посилення конкуренції однорідних товарів на усталених ринках робить участь у гонці медіа-озброєнь все дорожчою. Українські бренди починають активно освоювати нові цифрові канали комунікації. Але поки їх використовують як рекламоносії, розміщують рекламу в традиційному стилі мегафона, не намагаючись максимально використовувати потенціал цих нових медіа та цифрових технологій.

Отже, спостерігаємо інтеграцію традиційних і нових каналів комунікації, де широко використовуються нові форми і технології, але наповнення поки що залишається звичним. При цьому можна спостерігати, як цифрові взаємини все глибше проникають у наше суспільство, змінюючи й споживачів, і правила гри. Досить згадати і перебіг президентської виборчої кампанії Володимира Зеленського, яка пройшла під знаком цифрових технологій, як колись, у 2008 році, президентська кампанія Барака Обами. Можна згадати й нові цифрові програмні додатки, зокрема «Дія», що активно входять у наш побут, змінюючи звички. Та й карантинні обмеження сприяли стимулюванню переходу в онлайновий простір все більшого числа населення і компаній. Так, Андрій Длігач зазначає: «З огляду на те, що українці шаленими темпами йдуть в інтернет і швидкими темпами розвивається споживання категорій в інтернеті, усім потрібно знаходити свою територію в інтернеті» (Dlihach, 2018). А це означає, що кількість рано чи пізно перейде в якість і маркетингова комунікація в Україні буде здійснюватися в рамках нових підходів.

\section{4. Висновок}

Розвиток цифрових технологій та Інтернету, особливо мобільного, привели до зміни моделі поведінки і звичок більшості людей. Традиційні канали й форми комунікації, які раніше користувалися беззастережним авторитетом, сьогодні не працюють. Їх ефективність знизилася не тільки через появу незліченної кількості альтернативних джерел інформації та через розсіювання уваги споживача в зв'язку з цим. Відбулася зміна авторитетів у свідомості споживача. Стрімкий розвиток горизонтальних зв'язків і взаємопов'язаності завдяки соціальним мережам зруйнував авторитет брендів на користь кола спілкування кожного споживача. Тепер він більше довіряє друзям і родичам або блогерам, ніж торговій марці. Характер комунікації теж змінився. Він більше не односторонній. Будь-яку інформацію споживач сьогодні може знайти самостійно. Його більше цікавить спілкування, у рамках якого він може отримати дружню пораду, рекомендацію чи допомогу у вирішенні проблеми, яка його турбує особисто, або просто розважитися. Він прагне індивідуального ставлення та можливості змінюватися за допомогою бренда. Всі ці зміни вимагають перегляду підходів до маркетингової комунікації не тільки в частині форми та технології, але й в частині змісту. В усвідомленні неминучості та необхідності змін лежить запорука майбутньої успішності брендів на ринку.

\section{References}

Arieli, D. (2018). Peredbachuvana irazionalnist [Predictable Irrationality]. Vidavnitstvo Starogo Leva (in Ukrainian).

Barden, P. (2014). Vzlom marketinga: Nauka o tom, pochemy mi pokupaem [Hacking Marketing: The science of why we buy]. Mann, Ivanov i Ferber (in Russian).

Berher, J. (2016). Zarazlyvyi [Contagious]. Nash Format (in Ukrainian).

Dlihach, A. (2018). Pro viinu brendiv za formuvannia kultur [About the war of brands for the formation of cultures]. Trademaster. https://trademaster.ua/marketing_i_prodazhi/312826?utm (in Ukrainian).

Eial, N. (2017). Na hachku. Yak stvoriti product, sho chiplyae [On the hook. How to create a sticky product]. Nash Format (in Ukrainian).

Godin, S. (2014). Fioletovaya korova. Sdelayte svoy biznes vidaushimsya! [Purple cow. Make your business outstanding!]. Mann, Ivanov i Ferber (in Russian).

Helligen, B. (2020). Vkhidnyi marketynh: Pryvabliuite, zaluchaite i raduite onlain [Inbound Marketing: Attract, attract and rejoice online]. Ranok (in Ukrainian)

Kahneman, D. (2020). Dumay medleno... reshay bistro [Thinking, fast and slow]. Fors (in Russian).

Kim, W. Chan, Moborn, R. (2019). Stratehiia blakytnoho okeanu. Yak stvoryty bezkhmarnyi rynkovyi prostir i pozbutysia konkurentsii [Strategy of the blue ocean. How to create a cloudless market space and get rid of competition]. Klub Simeynogo dozvillya (in Ukrainian).

Kingsnort, S. (2019). Strategiya zifrovogo marketinga. Integrirovaniy podhod $k$ onlayn-marketingu [Digital marketing strategy. An integrated approach to online marketing]. Olimp-Bisnes (in Russian).

Kotler, F. (2010). Lateralniy marketing: tehnologiya poiska revoluzionih idey [Lateral marketing: technology for finding revolutionary ideas]. Alpina Publisher (in Russian).

Kotler, F. (2019). Marketynh 4.0. vid tradytsiinoho do tsyfrovoho [Marketing 4.0. from traditional to digital]. KMBOOKS group (in Ukrainian).

Lewis, D. (2015). Neyromarketing $v$ deystvii. Kak proniknut $v$ mozg pokupatelya [Neuromarketing in action. How to get into the buyer's brain]. Mann, Ivanov i Ferber (in Russian).

Mackie, R. (2019). Storinomika: marketynh u postreklamnu epokhu [Storinomics: marketing in the post-advertising era]. Vivat (in Ukrainian).

Makki, R. (2018). Istoriya na million dollarov. Master-klass dlya szenaristov, pisateley I ne tolko [A story for a million dollars. Master class for screenwriters, writers and more]. Alpina Publisher (in Russian).

Pain, D., Hilmor, D. (2021). Economica vpechatleniy: Kak prevratit pokupku $v$ zachvativaushee deystvie [Economics of impressions: How to turn a purchase into an exciting action]. Vivat (in Ukrainian).

Stelzner, M. (2012). Kontent-marketing. Novie metodi privlecheniya klientov $v$ epohu Interneta [Content Marketing. New methods of attracting customers in the age of the Internet]. Mann, Ivanov i Ferber (in Russian).

Taleb, N. (2017). Chornyi lebid. Pro (ne)imovirne u realnomu ziti [Black Swan. About the (un) probable in real life]. Nash Format (in Ukrainian). 
Thaler R. (2016). Novaya povedencheskaya ekonomika. Pochemu ludi narushaut pravila tradizionnoy ekonomiki I kak na etom zarabotat [New behavioral economics. Why do people break the rules of the traditional economy and how to make money on it]. Bombora (in Russian).

Thompson, D. (2018). Hitmeykeri. Nauka populyarnosti v epohu razvlecheniy [Hitmakers. The Science of Popularity in the Age of Entertainment]. Azbuka (in Russian).
Traindl, A. (2007). Neyromarketing: Vizualizaziya emoziy [Neuromarketing: Visualization of emotions]. Alpina Business Books (in Russian).

Trout, D. (2007). Novoe pozizionirovanie. Vse o bisnes-strategii №1 $v$ mire [New positioning. All about business strategies №1 in the world]. Pyter (in Russian)

Trout, D. (2020). Marketinhovi viiny [Marketing Wars]. Ranok (in Ukrainian).

\section{Demchenko M. Marketing communication in the post-advertising era and Ukrainian practice}

The formation of a digital society and digital consumer, thanks to the development of digital technologies and the Internet, especially mobile, requires a change in the approach to marketing communication. Traditional channels and forms of communication are no longer as effective as they used to be. They are gradually losing credibility and audience attention. This is not only due to the emergence of countless alternative sources of information, which distracts the attention of the consumer. The rapid development of horizontal connections and interconnection, thanks to social media, has destroyed the credibility of brands in favor of each consumer's circle of friends. Now he trusts his friends, relatives or bloggers more. The nature of communication has also changed. It is no longer one-sided. The new format of communication involves cooperation and exchange, during which the consumer expects to receive friendly advice, recommendation or help in solving the problem that worries him personally, or just to have fun. He strives for individual attitude and the ability to change with the help of the brand. All this requires a revision of approaches to marketing communication. Which is not only about using digital technology and data. But also in changing the concept of the relationship between the brand and the consumer. The article talks about what the new approach in modern marketing communication is and how this new approach is being implemented in Ukrainian practice.

Keywords: marketing; communication; consumer; digital technologies; social networks; neuromarketing; storyline. 